\title{
Analysis of Understanding of Midwife Students of Midwife Care as the Impact of Online Learning
}

\author{
Nursyahraeni Madika Rahman \\ Midwifery Studies Program, Hasanuddin University, Makassar, Indonesia \\ Corresponding author email: saraheni32@gmail.com

\section{Sutina Made} \\ Economics of Fisheries Companie, Hasanuddin University, Makassar, Indonesia \\ Email: smade_icmi@yahoo.co.id
}

\author{
Andi Nilawati Usman \\ Midwifery Study Program, Hasanuddin University, Makassar, Indonesia \\ Email: nilawatiandi@pasca.unhas.ac.id

\section{Irfan Idris} \\ Department Of Physiology, Faculty of Medicine, Hasanuddin University, Makassar, Indonesia \\ Email: irfanfaal@gmail.com
}

\author{
Alimuddin Unde \\ Head of Research Institute and Community Service, Hasanuddin University, Makassar, Indonesia \\ Email: undealimuddin@yahoo.co.id

\section{Burhanuddin Bahar} \\ Science of nutrition Study Program, Hasanuddin University, Makassar, Indonesia \\ Email: burhanuddin@yahoo.co.id
}

\begin{abstract}
The purpose of this study was to analyze the understanding of midwifery students towards midwifery care as a result of online learning at the midwifery academy of Tahirah Al Baeti Bulukumba. This study is a quantitative descriptive study, a form of activity by measuring the level of understanding of students to family planning midwifery care as a result of online learning and probability sampling techniques with a total of 45 respondents. Analysis of data in this study is obtained from research instruments in the form of quantitative data. Quantitative data are obtained from the results of data processing case tests and surveys. The results of the study of Student Understanding Before and During the COVID-19 Pandemic on the creation of Family Planning Midwifery Care, namely an increase in understanding of the creation of family planning midwifery care by 20\%, shows that students actively remain disciplined in carrying out learning activities through online, namely by self-study after online learning and able to understand the lecture materials provided by lecturers.

Keywords---COVID-19, midwife students, midwifery care, online learning, understanding.
\end{abstract}

\section{Introduction}

As a result of the lockdown, in the world of education the learning process uses online methods that originally used face-to-face learning methods, online learning is one of the online learning methods done through the internet network (Hatmo, 2021). Online learning methods are learning that is done virtually, through the available 
applications, but online learning must still pay attention to the competencies to be taught. Educators should be aware that online learning has a complex nature because it involves pedagogical, psychological, and active aspects simultaneously (Yuliana et al., 2021). Online learning is a learning system that is done that is not facing to face but uses applications that can help in the learning process that is done even from a distance (Silvester et al., 2021).

The competence that is expected to be obtained from midwifery education is the ability to integrate cognitive, affective, and psychomotor while providing obstetric care and safe in any regulation. These competencies include basic or core competencies as well as additional competencies (Wimmer \& Perner, 1983; Gilbert \& CordeyHayes,1996). Additional competencies are knowledge or additional skills that must be learned and possessed by midwives depending on the needs of the local community (Ghita et al., 2021). It is this variation that distinguishes each country or region (Febriani et al., 2021).

Based on the results of interviews with lecturers and academic employees at Midwifery Academy Tahirah AlBaety Bulukumba found that graduates of Midwifery Academy Tahirah Al-Baety Bulukumba students can pass the graduation limit score for competency exams are very low. In a study conducted by Lismanda (2020), about the use of zoom application in education statistics lectures at Islamic universities. The results of this study revealed that online learning using the zoom application is quite effective for online lecture media. There has been no research on the analysis of the obstetric understanding of midwifery care as a result of online learning (Harvey et al., 2002; Benjamin et al., 2001).

\section{Research Methods}

This election pen is carried out in the midwifery Academy Tahirah Al-Baety Bulukumba. The type of research used is a quantitative descriptive research method. The population in this study was all students of the Academy of Midwifery Tahirah Al-Baety in the Academic Year 2020-2021. A sample of 45 people who sampling techniques using Probability sampling with simple random sampling technique, namely researchers choose a sample of criteria or with certain considerations set by the researcher with criteria and who have been willing to follow this study by signing informed consent. Data collection is carried out by researchers using primary data obtained directly from respondents using Case Study Tests and surveys through google form and Data obtained from the Academy of Midwifery Tahirah Al-Baety Bulukumba on the Number of Students and asked values. Data analysis techniques in Descriptive Statistics.

\section{Result and Discussion}

Figure 1 Student Opinion Regarding the Percentage of Absorption of PJJ Material Online in midwifery students in Midwifery Academy Tahirah Al-Baety Bulukumba In 2021.

\section{THEORY ABSORPTION RATE}

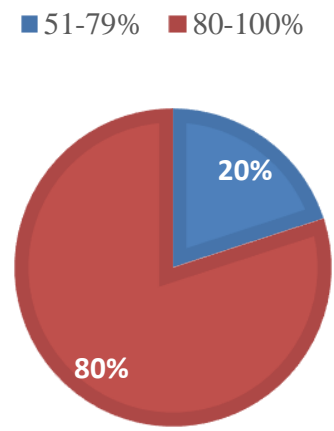

Figure 1. Theory absorption rate

Based on Figure 1 shows that there are 6 responses (20\%) are in the category of simply absorbing distance learning material online, while $39(80 \%)$ respondents are in the category of good or able to absorb well distance learning material online. 
Table 1

Analysis of students before and during the covid-19 pandemic on the creation of family planning midwifery care in midwifery academy Tahirah Al-Baety Bulukumba in 2021

\begin{tabular}{lccl}
\hline Value & $\begin{array}{c}\text { Before COVID } \\
\text { Percentage } \\
\mathrm{n}(\%)\end{array}$ & $\begin{array}{c}\text { During COVID } \\
\text { Percentage } \\
\mathrm{n}(\%)\end{array}$ & Value \\
\hline Good & $17(37.8)$ & $26(57.8)$ & $0.108^{*}$ \\
Enough & $28(62.2)$ & $19(42.2)$ & \\
Less & - & - & \\
Total & 45 & 100 & \\
\hline
\end{tabular}

Based on table 1 shows that before COVID student understanding of midwifery care there were $37.8 \%$ of respondents in the Good category, while $62.2 \%$ of respondents were in the Enough category. And during the pandemic COVID student understanding of midwifery care, $57.8 \%$ of respondents were in a Good category, while $42.2 \%$ of respondents were in the Enough category. Through Online Learning there was an increase in understanding of the creation of family planning midwifery care by $20 \%$, based on statistical tests, there was no significant difference in student understanding before and during the COVID-19 pandemic (Zhai \& Du, 2020).

Through Online Learning there is an increased understanding of the creation of family planning midwifery care by $20 \%$ The results of this study show that students actively remain disciplined in carrying out learning activities online, namely by self-study after online learning and able to understand the lecture materials provided by the lecturers (Malott et al., 2009; Mustafa et al., 2020). The ability to learn independently is characteristic of online learning (Moore et al., 2011; Sit et al., 2005). In online learning, it is necessary to be skilled in learning independently. Because at the time of the learning process, students will search, find and conclude that have been studied independently. As Handayani et al. (2013), point out, self-learning is a process by which students are directly involved in identifying what needs to be learned to be the holder of control in the learning process. When learning independently, the element of motivation becomes so important for the development of success in the learning process.

\section{Conclusion}

This study concluded that the Student Understanding of family planning midwifery care is understanding and there was a $20 \%$ increase as a result of online learning, although there was no significant difference in the understanding of students before and during the COVID-19 pandemic in midwifery DIII students.

\section{Acknowledgments}

The researcher would like to express her thankfulness to all the staff and lecturers who helped the researcher by permitting her to do her research from April to June toward the midwifery student 3- Years Diploma at Midwifery Academy Tahirah Al-Baety Bulukumba.

\section{References}

Benjamin, Y., Walsh, D., \& Taub, N. (2001). A comparison of partnership caseload midwifery care with conventional team midwifery care: labour and birth outcomes. Midwifery, 17(3), 234-240. https://doi.org/10.1054/midw.2001.0257

Febriani, D. A., Hafid, A., \& Sudirman, S. (2021). Analisis Efektivitas Pembelajaran Tematik melalui Daring di Kelas IV SD Inpres 6/86 Biru. JPPSD: Jurnal Pendidikan dan Pembelajaran Sekolah Dasar, 1(1), 45-58.

Ghita, D. ., Ahmad, M. ., Budi, P., Liantanty, F. ., \& Ahmar, H. . (2021). Effect of e-module stage iv childbirth care with blended learning model on skills improvement of midwifery students. International Journal of Health \& Medical Sciences, 4(1), 110-116. https://doi.org/10.31295/ijhms.v4n1.1527

Gilbert, M., \& Cordey-Hayes, M. (1996). Understanding the process of knowledge transfer to achieve successful technological innovation. Technovation, 16(6), 301-312. https://doi.org/10.1016/0166-4972(96)00012-0

Handayani, L., Nyoman, N., Dantes, N., \& Suastra, I. W. (2013). Pengaruh Model Pembelajaran Mandiri Terhadap Kemandirian Belajar dan Prestasi Belajar IPA Siswa Kelas VIII SMP N 3 Singaraja (Doctoral dissertation, Ganesha University of Education). 
Harvey, S., Rach, D., Stainton, M. C., Jarrell, J., \& Brant, R. (2002). Evaluation of satisfaction with midwifery care. Midwifery, 18(4), 260-267. https://doi.org/10.1054/midw.2002.0317

Hatmo, S. H. D. (2021). Dampak Pandemi Covid-19 Terhadap Efektivitas Pembelajaran Jarak Jauh Secara Daring. Scholaria: Jurnal Pendidikan dan Kebudayaan, 11(2), 115-122.

Hunter, L. P., \& Hunter, L. A. (2006). Storytelling as an educational strategy for midwifery students. Journal of Midwifery \& Women's Health, 51(4), 273-278. https://doi.org/10.1016/j.jmwh.2005.12.004

Licqurish, S., \& Seibold, C. (2008). Bachelor of Midwifery students' experiences of achieving competencies: The role of the midwife preceptor. Midwifery, 24(4), 480-489. https://doi.org/10.1016/j.midw.2007.05.001

Lismanda, Y. F. (2020). Use-Technical Skills Mahasiswa PIAUD Unisma Dalam Literasi Media Digital. Widyagogik: Jurnal Pendidikan dan Pembelajaran Sekolah Dasar, 7(2), 139-147.

Malott, A. M., Davis, B. M., McDonald, H., \& Hutton, E. (2009). Midwifery care in eight industrialized countries: how does Canadian midwifery compare?. Journal of Obstetrics and Gynaecology Canada, 31(10), 974-979. https://doi.org/10.1016/S1701-2163(16)34328-6

Moore, J. L., Dickson-Deane, C., \& Galyen, K. (2011). e-Learning, online learning, and distance learning environments: Are they the same?. The Internet and higher education, 14(2), 129-135. https://doi.org/10.1016/j.iheduc.2010.10.001

Mustafa, A. R., Ramadany, S., Sanusi, Y., Made, S., Stang, S., \& Syarif, S. (2020). Learning media applications for toddler midwifery care about android-based fine motor development in improving midwifery students skills. International Journal of Health \& $\quad$ Medical Sciences, 3(1), 130-135. https://doi.org/10.31295/ijhms.v3n1.290

Silvester, S., Purnasari, P. D., \& Sumarni, M. L. (2021). Efektivitas Penerapan Media Pembelajaran Daring Pada Pembelajaran Tematik Sekolah Dasar Negeri 02 Bengkayang. Sebatik, 25(2), 411-417.

Sit, J. W., Chung, J. W., Chow, M. C., \& Wong, T. K. (2005). Experiences of online learning: students' perspective. Nurse education today, 25(2), 140-147. https://doi.org/10.1016/j.nedt.2004.11.004

Wimmer, H., \& Perner, J. (1983). Beliefs about beliefs: Representation and constraining function of wrong beliefs in young children's understanding of deception. Cognition, 13(1), 103-128. https://doi.org/10.1016/00100277(83)90004-5

Yuliana, Y., Anindita, H. A., \& Syaifuddin, M. W. (2021). Pengaruh Konsentrasi Belajar dan Lingkungan Belajar terhadap Hasil Belajar Matematika pada Pembelajaran Daring. PRISMA, 10(2), 141-155.

Zhai, Y., \& Du, X. (2020). Addressing collegiate mental health amid COVID-19 pandemic. Psychiatry research, 288, 113003. https://doi.org/10.1016/j.psychres.2020.113003 